\title{
The impact of generic substitution on the activities of pharmaceutical companies - a survey from the companies' perspective one year and five years after the introduction of generic substitution in finland
}

\author{
Johanna Timonen ${ }^{1 *}$, Marina Bengtström², Pekka Karttunen ${ }^{3}$, Riitta Ahonen ${ }^{1}$
}

\begin{abstract}
Background: Mandatory generic substitution (GS) was introduced in Finland on 1 April 2003. The aim of this study was to explore and compare the impacts of GS on the activities of pharmaceutical companies representing mainly original or generic pharmaceutical products in Finland. The self-reported impact of GS from pharmaceutical companies' perspective was explored with a focus on the number of employees, the range of sales packages on the market, the marketing activities, the research and development of new pharmaceutical products and storage of pharmaceuticals.
\end{abstract}

Methods: A cross-sectional postal survey was conducted among pharmaceutical companies with an office in Finland and substitutable medicines in the Finnish pharmaceutical market one year (2004) and five years (2008) after the introduction of GS. Completed questionnaires were returned by 16 original and 7 generic product companies in 2004 (response rate 56\%, $\mathrm{n}=41$ ) and by 16 original and 6 generic product companies in 2008 (response rate $56 \%, n=39$ ). Descriptive statistical analyses were performed.

Results: The number of employees (2004: $n=6 / 16,2008: n=7 / 16)$ and the amount of prescription medicine marketing (2004: $n=7 / 16,2008: n=8 / 16$ ) decreased in many of the original product companies after the introduction of GS. GS resulted in problems related to the storage of pharmaceuticals in the original product companies shortly after GS was introduced ( $p=0.032$ between 2004 and 2008). In the generic product companies, the prescription medicine representatives' visits to pharmacies increased at the beginning of GS ( $p=0.021$ between 2004 and 2008). In addition, GS caused problems with the storage of pharmaceuticals one year and five years after the reform (2004: $n=4 / 7,2008: n=3 / 6)$. The differences between original and generic product companies regarding the impacts of GS were not, however, statistically significant. GS did not affect on the range of sales packages on the market or the research activities of the majority of companies.

Conclusions: The study suggests that GS has had impacts on the activities of pharmaceutical companies in Finland. There were also some differences, although not statistically significant, between the surveyed original and generic product companies regarding the self-reported impacts of GS. More investigations are needed in this field.

\footnotetext{
* Correspondence: johanna.timonen@uef.fi

'School of Pharmacy/Social Pharmacy, Faculty of Health Sciences, Kuopio Campus, University of Eastern Finland, P.O.Box 1627, Fl-70211 Kuopio,

Finland

Full list of author information is available at the end of the article
} 


\section{Background}

Increasing pharmaceutical expenditures have been a common problem in many western countries. One way to curb growth in pharmaceutical expenditures is through generic substitution (GS). GS has been introduced in at least 22 European countries [1-3] and in most states in the United States [4]. The purpose of GS is to increase dispensing of less expensive generic medicines and to decrease the price of pharmaceutical products through price competition. GS has successfully promoted the sales of less expensive medicines [5-7] and decreased the prices of pharmaceutical products [8-11] in several countries, and thus has effectively reduced growth in the pharmaceutical expenses of society and patients, for example in Sweden [12] and Finland [13].

GS has been a considerable pharmaceutical policy reform in many countries, not merely for society and patients, but also for parties involved in the pharmaceutical distribution chain (pharmaceutical companies, wholesale pharmaceutical companies and pharmacies). Even though GS has been introduced in many countries, there is a limited number of research publications in this area. Several studies have investigated pharmacists' opinions regarding GS and the implementation of GS in pharmacies in different countries [14-18]. Some studies have reported pharmacy owners' experiences of the impacts of GS on pharmacies in Denmark [15] and Finland [19]. The impact of GS on the activities of wholesale pharmaceutical companies [20], as well as the impact of GS on the sales of pharmaceutical companies [7] have been explored in Finland. However, there are no published studies concentrating on the impacts of GS on the activities, other than competition [8,10,11], of pharmaceutical companies.

Mandatory GS was introduced in Finland on 1 April 2003. Since then pharmacists have been obligated to substitute the least expensive or close to the least expensive medicine for a prescribed medicine if the prescribed medicine is not within the price corridor and the physician or the customer do not object to the substitution [21]. The price corridor is determined quarterly by the least expensive medicine in every substitution group, and it includes all the substitutable medicines with a price difference of less than $€ 2$ in products priced under $€ 40$, and of less than $€ 3$ in products priced $€ 40$ or more. Substitutable medicines are included on a list of interchangeable medicines compiled by the Finnish Medicines Agency [22]. Interchangeable medicines contain the same active ingredient in the same quantity, have the same pharmaceutical form (exception: tablets are substitutable for capsules and capsules for tablets), are bioequivalent and belong to a pharmaceutical group in which substitution can be performed safely. At the beginning of 2009, the list of interchangeable medicines comprised about $42 \%(n=2797)$ of the human pharmaceutical products with a marketing authorization in Finland $(\mathrm{n}=6$ 694) [23].

Between 2003 and 2008, GS was possible for 12-24 million prescriptions reimbursed annually [21]. Customers objected to GS for $10-12 \%$ of dispensings and physicians objected for $0.2-0.4 \%$ of dispensings. The annual direct savings of the substitutions for patients and for society have been $€ 26-36$ million. GS also stimulated significant price competition between pharmaceutical companies [11], and estimated savings from the reduced price of medicines have been $€ 34-59$ million annually [13,21].

The pharmaceutical industry objected to GS before it was introduced $[24,25]$. According to the research-based pharmaceutical industry, promoting the use of generic products was desirable, but it should be achieved by allowing normal competitive mechanisms to function, not by mandatory GS [24]. In addition, it was argued that GS would have an impact on the pharmaceutical companies and their everyday activities, such as marketing [26] and the storage of pharmaceutical products [24]. It was also argued that GS would raise drug safety issues $[24,26]$, decrease the range of different packages (e.g. strength, size, pharmaceutical form) of pharmaceutical products for sale, and reduce incentives for research and development of new pharmaceutical products in Finland [27].

The aim of this study was to explore and compare the impact of GS on the activities of pharmaceutical companies representing mainly original or generic pharmaceutical products from the companies' perspective one year and five years after the introduction of GS in Finland. The self-reported impact of GS was explored with a focus on the number of employees, marketing activities, the range of sales packages on the market, research and development (R\&D) of new pharmaceutical products and storage of pharmaceuticals. Results reported in this article are part of a larger study exploring the impact of GS for pharmaceutical companies in Finland. Results concerning impact of GS on the turnover and gross margin of pharmaceutical companies have been published elsewhere [7].

\section{Methods}

Two cross-sectional postal surveys were conducted one year (June-August 2004) and five years (November 2007-January 2008) after the introduction of GS. Questionnaires were sent to all pharmaceutical companies with an office in Finland and that market one or more substitutable medicines in Finland. The questionnaire was addressed to the key person in the company, such as the managing director or the sales and marketing director. The list of companies was obtained from the National Agency for Medicines' (NAM) list of the 
domestic holders of marketing authorization and Pharma Industry Finland's (PIF) list of member companies. The NAM list included pharmaceutical companies that have Finland as their home country in the NAM's register and that hold one or more valid marketing authorizations in Finland. PIF is a trade association for research-based pharmaceutical companies in Finland and most research-based pharmaceutical companies operating in Finland are members of PIF.

The Finnish pharmaceutical reference book (Pharmaca Fennica) on the Internet, and the current list of interchangeable medicines produced by NAM, were used to verify which companies marketed substitutable medicines in Finland. In 2008, the Medicinal product search service at the NAM's web site was also used, but it did not exist in 2004.

The lists of the NAM and PIF included 95 pharmaceutical companies or other parties operating in the Finnish pharmaceutical market in 2004. Of these, 43 pharmaceutical companies fulfilled the inclusion criteria (marketed substitutable medicines in the Finnish pharmaceutical market and had an office in Finland). The questionnaire was posted to all these 43 companies. After one reminder, 25 (58\%) questionnaires were returned. However, two of the returned questionnaires were not included in the study because the company reported that they did not presently have substitutable medicines in the Finnish pharmaceutical market. Consequently, a total of 41 pharmaceutical companies (25 represented original products, 9 represented generic products and 7 represented both products) fulfilled the inclusion criteria, from which 23 (56\%) companies returned completed and usable questionnaire.

In 2007-2008, the lists of the NAM and PIF contained 93 pharmaceutical companies or other parties operating in Finland. The questionnaire was sent to all 39 pharmaceutical companies (19 represented original products, 10 represented generic products, 7 represented both products and 3 represented parallel imported products) that marketed substitutable medicines in the Finnish pharmaceutical market and had an office in Finland. Of these companies, 29 were the same as in 2004. Three reminders were needed in the 2008 survey to achieve the same response rate than in 2004. After three reminders, 23 (59\%) companies returned the questionnaire. However, one of the returned questionnaires was not complete and it was not included. Consequently, a total of 22 (56\%) questionnaires were included in the final data analyses.

In 2004, the survey questionnaire included 37 structured or open-ended questions and one Likert-scale question. Responses to seven structured questions and two open-ended questions are reported in this article. In 2007-2008, the questionnaire included 27 questions, both structured and open-ended. The questions reported in this article were the same in 2004 and in 2007-2008, with the exception the minor changes described below. The questions related to the impact of GS on the number of employees, the amount of prescription medicine marketing, the prescription medicine representatives' visits to pharmacies and to physicians, the number of different packages of pharmaceutical products for sale, $R \& D$ of new pharmaceutical products and storage of pharmaceuticals. The questions were selected on the basis of debate about the possible impact of GS before it was introduced. The self-reported impact of GS on the number of employees, marketing activities, the range of packages for sale and R\&D was elicited using similar structured questions. For example, the impacts of GS on the number of employees in the company were investigated with question, "Has generic substitution influenced the number of employees in your company?". The question had four response options: 1 . No, 2 . The number of employees has decreased, 3 . The number of employees has increased, 4. Some other impact. In the fourth response option, the respondents were also requested to report what kind of impact. If the respondent answered that the number of employees had increased or decreased, they were asked to specify by how many employees. Respectively, if the respondent answered that the number of packages for sale had increased or decreased, they were asked to specify by the decrease or increase per cent in the number of packages. In 2004, an open-ended question was used to determine which department within each company was most impact on the number of employees by GS. In the 2007-2008 survey this information was sought using a structured question formulated using the results of the 2004 survey. The impact of GS on the storage of pharmaceuticals was investigated using a structured question with a list of seven options in 2004 and eight options in 2008 , with respondents given the possibility to select several options. In all questions in 2004 and 2007-2008 surveys, the impact was assessed since the introduction of GS in Finland.

The data were analyzed with SPSS 14.0 statistical software. A descriptive approach was used in the analyses, using frequencies and cross-tabulations and Fisher's Exact test for a group comparison within the survey and between the surveys. Differences in the background characteristics between study companies in the 2004 and 2008 surveys were tested with Fisher's Exact tests and Mann-Whitney $U$ tests. The significance level was defined as p-values $\leq 0.05$.

\section{Results}

\section{Background characteristics}

Of the pharmaceutical companies that responded to the survey in 2004, 12 represented original products, 4 represented generic products and 7 represented both 
original and generic products. Of the companies that represented both products, 4 companies reported that they represent mainly original products and 3 companies reported that they represent mainly generic products. Of the companies that responded to the survey in 2008, 13 represented original products, 3 represented generic products and 6 represented both. Of the companies that represented both, 3 companies reported that they represent mainly original products and 3 companies reported that they represent mainly generic products. Because the number of study companies was small, the companies were categorized as companies that represented mainly original pharmaceutical products (original product companies) and companies that represented mainly generic pharmaceutical products (generic product companies). The background characteristics of the study companies in the 2004 and 2008 surveys are shown in Table 1 . There were no statistically significant differences between the 2004 and 2008 survey groups of original product companies and generic product companies.

\section{Impact of GS on the number of employees}

GS was reported to affect on the number of employees in most (2004: $n=9 / 16,2008: n=9 / 16)$ of the original product companies in both surveys and in most $(n=5 / 7)$ of the generic product companies in the 2004 survey (Table 2). In the original product companies the number of employees decreased (2004: $n=6,2008: n=7)$, and in the generic product companies the number of employees increased (2004: $n=3)$. In the 2008 survey, most ( $n=4 /$ 6) of the generic product companies reported that GS had not impacted the number of employees, but the difference with the 2004 survey was not statistically significant $(p=0.283)$. In addition, the differences between the original and generic product companies were not statistically significant in the 2004 ( $\mathrm{p}=0.063)$ and $2008(\mathrm{p}=$ 0.814 ) surveys. Table 3 indicates that GS mainly affected the number of employees in the sales and marketing departments in the study companies.

Of the original product companies with a decreased number of employees (2004: $n=6,2008: n=7$ ), five in 2004 and four in 2008 reported a decrease in the number of employees since the introduction of GS. These companies reported a total decrease of 81 people (median 5, range 2-60) in the 2004 survey and 33 people (median 5.5, range 2-20) in the 2008 survey. In the 2008 survey, two of the original product companies reported an increase in number of employees, which was a total of five people.

For the generic product companies that reported increased number of employees in the 2004 survey $(\mathrm{n}=$ 3 ), the total increase was nine people (median 3, range 24) since the introduction of GS. For those companies that reported a decreased number of employees $(n=2)$ in the
2004 survey the total decrease was nine people. In the 2008 survey, only one of the generic product companies with a decreased number of employees gave the number of decreased employees, which was two employees.

\section{Impact of GS on the marketing of pharmaceutical products}

Table 4 summarizes the impact of GS on the marketing activities of the study companies. In both surveys, more than half $(2004: n=9 / 16,2008: n=9 / 16)$ of the original product companies reported that GS had impacted the amount of prescription medicine marketing. Of these, most companies (2004: $\mathrm{n}=7,2008: \mathrm{n}=8$ ) had decreased the amount of marketing after GS. In the generic product companies GS was reported to affect the prescription medicine representatives' visits to the pharmacies $(n=5 /$ 7 ) in the 2004 survey, but in the 2008 survey, most ( $\mathrm{n}=$ 5/6) of the generic product companies reported that GS had not affected the representatives' visits to pharmacies $(p=0.021)$. The differences between original and generic product companies in relation to their marketing activities were not statistically significant in the 2004 and 2008 surveys (Table 4).

\section{Impact of GS on the range of sales packages of pharmaceutical products on the market}

Most of the original product companies in both surveys (2004: $\mathrm{n}=8 / 15,2008: \mathrm{n}=8 / 14)$ and most of the generic product companies in the 2004 survey $(n=4 / 7)$ reported that GS had not impacted the number of different sales packages on the market (Table 5). In the 2008 survey, two-thirds $(n=4 / 6)$ of the generic product companies reported that GS had influenced the number of different packages for sale, but the differences between the companies $(\mathrm{p}=0.347)$ or surveys $(\mathrm{p}=$ 0.790 ) were not statistically significant.

Among the original product companies that reported a decrease in the number of sales packages on the market $(2004: \mathrm{n}=7 / 15,2008: \mathrm{n}=5 / 14)$ the median decrease in the number of packages was 10\% (range 0.5$20 \%$ ) in the 2004 survey. In the 2008 survey, three of the original product companies reported an average decrease of $15 \%$ (range 5-20\%) of packages sold. Among the two generic product companies that reported a decrease in the number of packages for sale in the 2004 survey, the number of packages had decreased 3\% and $10 \%$. In the 2008 survey the generic product companies that reported a decreased number of sales packages $(\mathrm{n}=$ 2) did not report the percentage decrease.

\section{Impact of GS on the R\&D of new pharmaceutical products in Finland}

In both surveys, the majority of original (2004: $\mathrm{n}=8 / 14$, 2008: $\mathrm{n}=8 / 12)$ and generic $(2004: \mathrm{n}=2 / 3,2008: \mathrm{n}=3 / 4)$ 
Table 1 Background characteristics of the study companies in the 2004 and 2008 surveys

\begin{tabular}{|c|c|c|c|}
\hline & $\begin{array}{c}\text { Survey } 2004 \\
\mathrm{n} \text { of respondents (\%) }\end{array}$ & $\begin{array}{c}\text { Survey } 2008 \\
\mathrm{n} \text { of respondents (\%) }\end{array}$ & P-value \\
\hline Number of companies & & & 1.000 \\
\hline All & 23 & 22 & \\
\hline Original products & $16(70)$ & $16(73)$ & \\
\hline Generic products & $7(30)$ & $6(27)$ & \\
\hline \multicolumn{4}{|l|}{ Number of employees } \\
\hline Original product companies & & & 0.732 \\
\hline$\leq 19$ & $1(7)$ & $4(25)$ & \\
\hline $20-49$ & $1(7)$ & $2(13)$ & \\
\hline 50-99 & $7(50)$ & $5(31)$ & \\
\hline 100-149 & $2(14)$ & $2(13)$ & \\
\hline$\geq 150$ & $3(22)$ & $3(19)$ & \\
\hline Generic product companies & & & 0.470 \\
\hline$\leq 19$ & $5(71)$ & $2(40)$ & \\
\hline 20-49 & - & - & \\
\hline $50-99$ & $2(29)$ & $1(20)$ & \\
\hline 100-149 & - & $1(20)$ & \\
\hline$\geq 150$ & - & $1(20)$ & \\
\hline \multicolumn{4}{|c|}{ Turnover of the companies $(€)^{a}$} \\
\hline Original product companies & & & 0.381 \\
\hline$\leq 1,000,000$ & - & - & \\
\hline $1,000,001-20,000,000$ & $1(7)$ & $6(37)$ & \\
\hline $20,000,001-40,000,000$ & $5(36)$ & $2(13)$ & \\
\hline $40,000,001-60,000,000$ & $3(22)$ & $3(19)$ & \\
\hline $60,000,001-80,000,000$ & $2(14)$ & $1(6)$ & \\
\hline $80,000,001-100,000,000$ & $1(7)$ & $2(13)$ & \\
\hline$\geq 100,000,001$ & $2(14)$ & $2(13)$ & \\
\hline Generic product companies & & & 0.755 \\
\hline$\leq 1,000,000$ & $1(14)$ & $1(17)$ & \\
\hline $1,000,001-20,000,000$ & $5(72)$ & $3(50)$ & \\
\hline $20,000,001-40,000,000$ & $1(14)$ & - & \\
\hline $40,000,001-60,000,000$ & - & $1(17)$ & \\
\hline $60,000,001-80,000,000$ & - & - & \\
\hline $80,000,001-100,000,000$ & - & - & \\
\hline$\geq 100,000,001$ & - & $1(17)$ & \\
\hline \multicolumn{4}{|c|}{$\begin{array}{l}\text { Median proportion (\%) of turnover coming from the sale of pharmaceutical products included on the list of interchangeable } \\
\text { medicines }\end{array}$} \\
\hline All & 25 (range 1.5-100) & 11 (range 1-93) & 0.749 \\
\hline Original product companies & 23 (range 1.5-80) & 8.5 (range 1-70) & 0.527 \\
\hline Generic product companies & 30 (range 5-100) & 45 (range 5.4-93) & 0.836 \\
\hline \multicolumn{4}{|c|}{ Median proportion (\%) of turnover coming from the sale of pharmaceutical products included in the price corridor ${ }^{\mathrm{b}}$} \\
\hline All & 10 (range 0-90) & 8.2 (range $0-90$ ) & 0.767 \\
\hline Original product companies & 7.5 (range $0-50$ ) & 3.5 (range $0-70$ ) & 0.608 \\
\hline Generic product companies & 30 (range 5-90) & 45 (range 5.4-90) & 0.836 \\
\hline \multicolumn{4}{|c|}{ Median market share (\%) in the Finnish pharmaceutical market ${ }^{b}$} \\
\hline All & 1.9 (range $0.1-10)$ & 1.9 (range 0.1-9) & 0.904 \\
\hline Original product companies & 3.8 (range 0.6-10) & 2.0 (range $0.3-8$ ) & 0.354 \\
\hline Generic product companies & 0.3 (range $0.1-2$ ) & 0.3 (range 0.1-9) & 0.662 \\
\hline
\end{tabular}

${ }^{\mathrm{a} T h e}$ companies reported their turnover from 2003 in the 2004 survey and from 2006 in the 2008 survey.

${ }^{\mathrm{b}}$ The companies reported their proportion (\%) from 2006 in the 2008 survey. 
Table 2 Impact of generic substitution on the number of employees in the pharmaceutical companies

\begin{tabular}{|c|c|c|c|c|c|c|c|c|}
\hline & \multicolumn{4}{|c|}{ Survey 2004} & \multicolumn{4}{|c|}{ Survey 2008} \\
\hline & $\begin{array}{c}\text { Original } \\
\text { product } \\
\text { companies } \\
n(\%)\end{array}$ & $\begin{array}{c}\text { Generic } \\
\text { product } \\
\text { companies } \\
\mathrm{n}(\%)\end{array}$ & $\begin{array}{l}\text { Total } \\
\text { n (\%) }\end{array}$ & $\begin{array}{c}\mathrm{P}- \\
\text { value }\end{array}$ & $\begin{array}{c}\text { Original } \\
\text { product } \\
\text { companies } \\
\mathrm{n}(\%)\end{array}$ & $\begin{array}{c}\text { Generic } \\
\text { product } \\
\text { companies } \\
\mathrm{n}(\%)\end{array}$ & $\begin{array}{l}\text { Total } \\
\text { n (\%) }\end{array}$ & $\begin{array}{c}\mathrm{P}- \\
\text { value }\end{array}$ \\
\hline $\begin{array}{l}\text { Has generic substitution influenced the } \\
\text { number of employees in your company?* }\end{array}$ & & & 0.063 & & & & & 0.814 \\
\hline No & $7(44)$ & $2(29)$ & $9(39)$ & & $7(44)$ & $4(67)$ & $11(50)$ & \\
\hline Number of employees has decreased & $6(37)$ & $2(29)$ & $8(35)$ & & $7(44)$ & $2(33)$ & $9(41)$ & \\
\hline Number of employees has increased & - & $3(43)$ & $3(13)$ & & $2(12)$ & - & $2(9)$ & \\
\hline Some other impact ${ }^{a}$ & $3(19)$ & - & $3(13)$ & & - & - & - & \\
\hline Total & $16(100)$ & $7(100)$ & $23(100)$ & & $16(100)$ & $6(100)$ & $22(100)$ & \\
\hline
\end{tabular}

* P-value between the 2004 and 2008 surveys in the original product companies $(p=0.210$ ) and in the generic product companies ( $p=0.283$ )

a Employees have been reassigned to another post, openings in the company have not been filled.

product companies that conducted R\&D of new pharmaceutical products reported that GS had not influenced their R\&D in Finland (Table 6).

Impact of GS on the storage of pharmaceutical products GS was reported to affect the storage of pharmaceutical products in most of the original $(n=12 / 16)$ and generic $(\mathrm{n}=4 / 7)$ product companies in the 2004 survey (Table 7). In the 2008 survey, most $(n=10 / 15)$ of the original product companies reported that GS had not impacted the storage of pharmaceutical products, and the difference compared to the responses of the original product companies in the 2004 survey was statistically significant $(\mathrm{p}=0.032)$. Of the generic product companies, half $(n=3 / 6)$ reported that GS had impacted the storage in the 2008 survey. In the original product companies GS had most often caused over-stocking (2004: $\mathrm{n}=9 / 16)$ and problems with the expiry dates (2004: $\mathrm{n}=7 / 16)$. Problems with expiry dates (2004: $\mathrm{n}=$ $4 / 7,2008: \mathrm{n}=3 / 6)$ and the availability $(2008: \mathrm{n}=3 / 6)$ of pharmaceutical products were the most commonly reported problems by the generic product companies. The differences between original and generic product companies were not, however, statistically significant.

\section{Discussion}

In this study the impacts of GS on the activities of pharmaceutical companies representing mainly original or generic pharmaceutical products were investigated one year and five years after the introduction of GS in Finland. The original product companies self-reported that GS had impacted the number of employees and the

Table 3 Companies' departments most impacted on the number of employees by the introduction of generic substitution

\begin{tabular}{|c|c|c|}
\hline & $\begin{array}{c}\text { Survey } 2004 \\
\text { Pharmaceutical companies } \\
(\mathrm{n}=11)^{\mathrm{a}} \\
\mathrm{n}(\%)^{\mathrm{b}}\end{array}$ & $\begin{array}{c}\text { Survey } 2008 \\
\text { Pharmaceutical companies } \\
(\mathrm{n}=11) \\
\mathrm{n}(\%)^{\mathrm{b}}\end{array}$ \\
\hline \multicolumn{3}{|l|}{ Number of employees has decreased } \\
\hline Sales and marketing & $6(54)$ & $8(73)$ \\
\hline Marketing authorization and reimbursement & - & $1(9)$ \\
\hline Research and development & - & $1(9)$ \\
\hline Logistics & - & - \\
\hline Management & - & $1(9)$ \\
\hline \multicolumn{3}{|l|}{ Number of employees has increased } \\
\hline Sales and marketing & $3(27)$ & $1(9)$ \\
\hline Marketing authorization and reimbursement & - & $1(9)$ \\
\hline Research and development & - & - \\
\hline Logistics & $1(9)$ & - \\
\hline Management & - & - \\
\hline \multicolumn{3}{|l|}{ Some other impact } \\
\hline Sales and marketing & $2(18)$ & - \\
\hline
\end{tabular}

a Two original product companies and one generic product company did not report the department, in which GS had influenced on the number of employees.

b The companies could report several departments. 
Table 4 Impact of generic substitution on the marketing of pharmaceutical products in the pharmaceutical companies

\begin{tabular}{|c|c|c|c|c|c|c|c|c|}
\hline & \multicolumn{4}{|c|}{ Survey 2004} & \multicolumn{4}{|c|}{ Survey 2008} \\
\hline & $\begin{array}{c}\text { Original } \\
\text { product } \\
\text { companies } \\
\mathbf{n}(\%)\end{array}$ & $\begin{array}{c}\text { Generic } \\
\text { product } \\
\text { companies } \\
\mathrm{n}(\%)\end{array}$ & $\begin{array}{l}\text { Total } \\
\text { n (\%) }\end{array}$ & $\begin{array}{c}\text { P- } \\
\text { value }\end{array}$ & $\begin{array}{c}\text { Original } \\
\text { product } \\
\text { companies } \\
\text { n (\%) }\end{array}$ & $\begin{array}{c}\text { Generic } \\
\text { product } \\
\text { companies } \\
n(\%)\end{array}$ & $\begin{array}{l}\text { Total } \\
\text { n (\%) }\end{array}$ & $\begin{array}{c}\mathrm{P}- \\
\text { value }\end{array}$ \\
\hline $\begin{array}{l}\text { Has generic substitution influenced the } \\
\text { amount of prescription medicine marketing?* }\end{array}$ & & & & 0.103 & & & & 1.000 \\
\hline No & $7(44)$ & $4(57)$ & $11(48)$ & & $7(44)$ & $3(50)$ & $10(45)$ & \\
\hline Marketing has decreased & $7(44)$ & $1(14)$ & $8(35)$ & & $8(50)$ & $3(50)$ & $11(50)$ & \\
\hline Marketing has increased & - & $2(29)$ & $2(9)$ & & $1(6)$ & - & $1(5)$ & \\
\hline Some other impact ${ }^{a}$ & $2(12)$ & - & $2(9)$ & & - & - & - & \\
\hline Total & $16(100)$ & $7(100)$ & $23(100)$ & & $16(100)$ & $6(100)$ & $22(100)$ & \\
\hline $\begin{array}{l}\text { Has generic substitution influenced } \\
\text { prescription medicine representatives' visits to } \\
\text { pharmacies?** }\end{array}$ & & & & 0.120 & & & & 0.619 \\
\hline No & $9(60)$ & $2(29)$ & $11(50)$ & & $10(62)$ & $5(83)$ & $15(68)$ & \\
\hline Visits have decreased & $2(13)$ & - & $2(9)$ & & $2(13)$ & $1(17)$ & $3(14)$ & \\
\hline Visits have increased & $3(20)$ & $5(71)$ & $8(36)$ & & $4(25)$ & - & $4(18)$ & \\
\hline Some other impact ${ }^{b}$ & $1(7)$ & - & $1(5)$ & & - & - & - & \\
\hline Total & $15(100)$ & $7(100)$ & $22(100)$ & & $16(100)$ & $6(100)$ & $22(100)$ & \\
\hline $\begin{array}{l}\text { Has generic substitution influenced } \\
\text { prescription medicine representatives' visits to } \\
\text { physicians?*** }\end{array}$ & & & & 1.000 & & & & 0.802 \\
\hline No & $10(63)$ & $5(71)$ & $15(65)$ & & $9(60)$ & $4(67)$ & $13(62)$ & \\
\hline Visits have decreased & $5(31)$ & $2(29)$ & $7(31)$ & & $5(33)$ & $1(17)$ & $6(29)$ & \\
\hline Visits have increased & - & - & - & & $1(7)$ & $1(17)$ & $2(9)$ & \\
\hline Some other impact ${ }^{c}$ & $1(6)$ & - & $1(4)$ & & - & - & - & \\
\hline Total & $16(100)$ & $7(100)$ & $23(100)$ & & $15(100)$ & $6(100)$ & $21(100)$ & \\
\hline
\end{tabular}

* P-value between the 2004 and 2008 surveys in the original product companies $(p=0.624)$ and in the generic product companies $(p=0.372)$.

** P-value between the 2004 and 2008 surveys in the original product companies $(p=1.000)$ and in the generic product companies $(p=0.021)$.

*** P-value between the 2004 and 2008 surveys in the original product companies $(p=1.000)$ and in the generic product companies $(p=1.000)$.

${ }^{a}$ Marketing of pharmaceutical products within generic substitution has ended, marketing has been segmented and allocated.

${ }^{\mathrm{b}}$ The content of marketing has been changed.

${ }^{\mathrm{C}}$ Marketing has been focused on pharmaceutical products that do not include generic substitution and on new products.

amount of prescription medicine marketing one year and five years after the introduction of GS. In addition, GS caused problems related to the storage of pharmaceutical products shortly after it was introduced. According to the generic product companies, GS affected the prescription representatives' visit to pharmacies at the beginning of the reform. Furthermore, GS caused problems with the storage of pharmaceutical products one year and five years after the introduction. However, the differences between original and generic product companies regarding the impacts of GS were not statistically significant in this study. This might be because of the small study population.

After the introduction of GS the number of employees had decreased in many of the original product companies and, especially in the sales and marketing departments. The findings are in line with the statistics of PIF, where the number of employees increased steadily between 1990 and 2002 [28], but decreased after 2003 almost without exception [29-33]. In contrast at a European level the number of employees in the pharmaceutical industry was stable during the same period [34]. In Finland, the estimation of the overall decrease in employees is about 800-900 people between 2003 and 2008, due to the mergers of companies and downsizing e.g. especially in the marketing, but also in R\&D [29-33]. In 2008, the total number of employees in the pharmaceutical industry was about 6000 people. GS stimulated competition in the Finnish pharmaceutical market $[11,35]$. Reducing the number of employees was one response to this new competition between the companies in Finland [7]. However, the decrease in the number of employees may also reflect increased competition in the pharmaceutical market globally.

Many of the original product companies also reported a decrease in the amount of prescription medicine marketing after GS. Original product companies often decrease their promotional activities (e.g. the marketing of product) when the generic competition begins [36]. In an earlier study, reduction in original product 


\begin{tabular}{|c|c|c|c|c|c|c|c|c|}
\hline & \multicolumn{4}{|c|}{ Survey 2004} & \multicolumn{4}{|c|}{ Survey 2008} \\
\hline & $\begin{array}{c}\text { Original } \\
\text { product } \\
\text { companies } \\
\mathrm{n}(\%)\end{array}$ & $\begin{array}{c}\text { Generic } \\
\text { product } \\
\text { companies } \\
\mathrm{n}(\%)\end{array}$ & $\begin{array}{l}\text { Total } \\
\text { n (\%) }\end{array}$ & $\begin{array}{c}\mathrm{P} \text { - } \\
\text { value }\end{array}$ & $\begin{array}{c}\text { Original } \\
\text { product } \\
\text { companies } \\
\mathrm{n}(\%)\end{array}$ & $\begin{array}{c}\text { Generic } \\
\text { product } \\
\text { companies } \\
\mathbf{n}(\%)\end{array}$ & $\begin{array}{l}\text { Total } \\
\text { n (\%) }\end{array}$ & $\begin{array}{c}\mathrm{P}- \\
\text { value }\end{array}$ \\
\hline $\begin{array}{l}\text { Has generic substitution influenced the number of } \\
\text { different sales packages of pharmaceutical products on } \\
\text { the pharmaceutical market in your company?*}\end{array}$ & & & & 0.318 & & & & 0.347 \\
\hline No & $8(53)$ & $4(57)$ & $12(54)$ & & $8(57)$ & $2(33)$ & $10(50)$ & \\
\hline The number of packages has decreased & $7(47)$ & $2(29)$ & $9(41)$ & & $5(36)$ & $2(33)$ & $7(35)$ & \\
\hline The number of packages has increased & - & $1(14)$ & $1(5)$ & & $1(7)$ & $2(33)$ & $3(15)$ & \\
\hline Total & $15(100)$ & $7(100$ & $22(100)$ & & $14(100)$ & $6(100)$ & $20(100)$ & \\
\hline
\end{tabular}

* P-value between the 2004 and 2008 surveys in the original product companies $(p=0.710)$ and in the generic product companies ( $p=0.790)$.

companies' marketing was one of the most commonly reported mechanism compensate for increased competition due to GS [7].

Generic product companies reported increased marketing activities directed to pharmacies in the early stage of GS. This is in line with a study conducted among Finnish pharmacists [37]. The finding is logical given that pharmacists play an important role when a patient decides whether or not to object to switching $[17,38,39]$. Marketing in the early stages following the introduction of GS may also provide a competitive advantage [40]. Previous Finnish studies have reported that GS has also changed the content of drug marketing directed to pharmacies, with a greater emphasis on price after GS [37,41].

Both the original and generic product companies reported difficulties in stock management, especially among the original product companies in the early stages of GS. Sales by the volume of generic pharmaceutical products have increased whereas sales by volume of original products have decreased after GS [42]. This may be one reason for some of the storage problems reported, such as overstocking by the original product companies. The market situation also changed more often after GS, because the price corridor is determined quarterly and prices of pharmaceutical products can be updated every two weeks. This also creates challenges for stock management. Previous studies have reported that stock management has also become more complicated in Danish [15] and Finnish [19] pharmacies as well as in Finnish wholesale pharmaceutical companies [20] due to GS.

Our findings did not strongly support the belief that GS would decrease the range of different packages (e.g. strength, size, pharmaceutical form) of pharmaceutical products for sale as it was anticipated before GS was introduced in Finland [27]. Furthermore, the results did not reveal that GS had impacted R\&D in pharmaceutical companies. However, there were several companies that reported they decreased the number of packages for sale

Table 6 Impact of generic substitution on research and development of new pharmaceutical products ${ }^{a}$

\begin{tabular}{|c|c|c|c|c|c|c|c|c|}
\hline & \multicolumn{4}{|c|}{ Survey 2004} & \multicolumn{4}{|c|}{ Survey 2008} \\
\hline & $\begin{array}{l}\text { Original } \\
\text { product } \\
\text { companies } \\
n(\%)^{a}\end{array}$ & $\begin{array}{c}\text { Generic } \\
\text { product } \\
\text { companies } \\
\text { n (\%) }\end{array}$ & $\begin{array}{c}\text { Total } \\
\mathrm{n}(\%)^{\mathrm{b}}\end{array}$ & $\begin{array}{c}\text { P- } \\
\text { value }\end{array}$ & $\begin{array}{l}\text { Original } \\
\text { product } \\
\text { companies } \\
n(\%)\end{array}$ & $\begin{array}{l}\text { Generic } \\
\text { product } \\
\text { companies } \\
\text { n (\%) }\end{array}$ & $\begin{array}{l}\text { Total } \\
\text { n (\%) }\end{array}$ & $\begin{array}{c}\text { P- } \\
\text { value }\end{array}$ \\
\hline $\begin{array}{l}\text { Has generic substitution influenced the } \\
\text { research and development of new } \\
\text { pharmaceutical products in Finland in } \\
\text { your company?* }\end{array}$ & & & & 0.161 & & & & 0.154 \\
\hline No & $8(57)$ & $2(67)$ & $10(59)$ & & $8(67)$ & $3(75)$ & $11(69)$ & \\
\hline $\begin{array}{l}\text { Research and development has } \\
\text { decreased }\end{array}$ & $5(36)$ & - & $5(29)$ & & $4(33)$ & - & $4(25)$ & \\
\hline $\begin{array}{l}\text { Research and development has } \\
\text { increased }\end{array}$ & - & $1(33)$ & $1(6)$ & & - & - & - & \\
\hline Some other impact ${ }^{c}$ & $2(14)$ & - & $2(12)$ & & - & $1(25)$ & $1(6)$ & \\
\hline Total & $14(107)$ & $3(100)$ & 17 (106) & & $12(100)$ & $4(100)$ & $16(100)$ & \\
\hline
\end{tabular}

* P-value between the 2004 and 2008 surveys in the original product companies $(p=0.594)$ and in the generic product companies ( $p=1.000$ )

a The table contains only the responses of companies that conducted research and development of new pharmaceutical products.

bone company chose two impacts (research and development has decreased and some other impact).

${ }^{c}$ For example, the research of pharmaceutical products within generic substitution does not interest no longer, research and development will be directed to new pharmacotherapy areas. 


\begin{tabular}{|c|c|c|c|c|c|c|c|c|}
\hline & & Survey 20 & & & & Survey 20 & & \\
\hline & $\begin{array}{c}\text { Original } \\
\text { product } \\
\text { companies } \\
(\mathrm{n}=16) \\
\mathrm{n}(\%)^{\mathrm{a}}\end{array}$ & $\begin{array}{c}\text { Generic } \\
\text { product } \\
\text { companies } \\
(\mathrm{n}=7) \\
\mathrm{n}(\%)^{\mathrm{a}}\end{array}$ & $\begin{array}{c}\text { Total } \\
(n=23) \\
n(\%)^{a}\end{array}$ & $\begin{array}{l}\mathrm{P}- \\
\text { value }\end{array}$ & $\begin{array}{c}\text { Original } \\
\text { product } \\
\text { companies } \\
(\mathrm{n}=15) \\
\mathrm{n}(\%)^{\mathrm{a}}\end{array}$ & $\begin{array}{c}\text { Generic } \\
\text { product } \\
\text { companies } \\
(\mathrm{n}=6) \\
\mathrm{n}(\%)^{\mathrm{a}}\end{array}$ & $\begin{array}{l}\text { Total } \\
(n=21) \\
n(\%)^{a}\end{array}$ & $\begin{array}{c}P- \\
\text { value }\end{array}$ \\
\hline $\begin{array}{l}\text { Has generic substitution influenced the storage of } \\
\text { pharmaceutical products by your company? }\end{array}$ & & & & & & & & \\
\hline $\mathrm{No}^{*}$ & $4(25)$ & $3(43)$ & $7(30)$ & 0.626 & $10(67)$ & $3(50)$ & $13(62)$ & 0.631 \\
\hline It has caused over-stocking** & $9(56)$ & $2(29)$ & $11(48)$ & 0.371 & $4(27)$ & $1(17)$ & $5(24)$ & 1.000 \\
\hline $\begin{array}{l}\text { It has caused problems with the expiry date of } \\
\text { pharmaceutical products*** }\end{array}$ & $7(44)$ & $4(57)$ & $11(48)$ & 0.667 & $3(20)$ & $3(50)$ & $6(29)$ & 0.291 \\
\hline $\begin{array}{l}\text { It has caused over-stocking of obligatory } \\
\text { stocks }^{\text {***** }}\end{array}$ & $4(25)$ & $1(14)$ & $5(22)$ & 1.000 & $3(20)$ & - & $3(14)$ & 0.526 \\
\hline $\begin{array}{l}\text { It has caused problems with the availability of } \\
\text { pharmaceutical products***** }\end{array}$ & $4(25)$ & $1(14)$ & $5(22)$ & 1.000 & $2(13)$ & $3(50)$ & $5(24)$ & 0.115 \\
\hline $\begin{array}{l}\text { It has complicated the execution of obligatory } \\
\text { storage }^{b} * * * * * *\end{array}$ & $2(12)$ & $1(14)$ & $3(13)$ & 0.684 & $2(13)$ & $1(17)$ & $3(14)$ & 1.000 \\
\hline $\begin{array}{l}\text { It has increased returns of pharmaceutical } \\
\text { products from pharmacies after the new price } \\
\text { corridor is determined }^{c}\end{array}$ & - & - & - & - & $2(13)$ & $1(17)$ & $3(14)$ & 1.000 \\
\hline $\begin{array}{l}\text { ** P-value between the } 2004 \text { and } 2008 \text { surveys in th } \\
\text { *** P-value between the } 2004 \text { and } 2008 \text { surveys in } t \\
\text { **** P-value between the } 2004 \text { and } 2008 \text { surveys in } \\
\text { **** P-value between the } 2004 \text { and } 2008 \text { surveys in } \\
\text { ***** P-value between the } 2004 \text { and } 2008 \text { surveys } \\
\text { a The companies could chose several impacts. } \\
\text { bIn Finland, pharmaceutical companies were obligat } \\
\text { medicines, analgesics) to cover ten or five months } \\
\text { products was based on the average sales of the pro } \\
\text { amended in } 2009 \text {. }\end{array}$ & $\begin{array}{l}\text { original produ } \\
\text { original prod } \\
\text { e original proc } \\
\text { he original pro } \\
\text { to store enoug } \\
\text { onsumption of } \\
\text { ct during the }\end{array}$ & $\begin{array}{l}\text { companies (p } \\
\text { ct companies (p } \\
\text { uct companies } \\
\text { luct companies } \\
\text { pharmaceutica } \\
\text { that product un } \\
\text { ariod from Janu }\end{array}$ & $\begin{array}{l}0.032) \text { and } \mathrm{i} \\
0.149 \text { ) and } \\
=0.252 \text { ) anc } \\
=1.000 \text { ) an } \\
=0.654) \text { a } \\
\mathrm{p}=1.000) \\
\text { products ir } \\
\text { il the end o } \\
\text { ry to Septer }\end{array}$ & $\begin{array}{l}n \\
\text { in the } g \\
\text { in the } \\
d \text { in the } \\
\text { certain } n \\
\text { he year } \\
\text { ser of th }\end{array}$ & $\begin{array}{l}\text { eric product con } \\
\text { eeric product co } \\
\text { eneric product c } \\
\text { eneric product } \\
\text { generic product } \\
\text { generic produc } \\
\text { nedicine groups } \\
\text { 2008. The oblig } \\
\text { e previous year. }\end{array}$ & $\begin{array}{l}\text { npanies }(p=1.0 \\
\text { mpanies }(p=1 \\
\text { ompanies }(p=1 \\
\text { companies }(p= \\
\text { companies }(p= \\
\text { t companies ( } p \\
\text { (e.g. antibiotics, } \\
\text { atory stock of } p \\
\text { The obligatory }\end{array}$ & $\begin{array}{l}0) . \\
00) . \\
000) . \\
000) \text {. } \\
0.266) \text {. } \\
1.000) \text {. } \\
\text { cardiovas } \\
\text { armaceut } \\
\text { torage Ac }\end{array}$ & \\
\hline
\end{tabular}

and the R\&D of new pharmaceutical products in Finland. Accordingly, more detailed research on these topics are needed.

The study had some limitations. The survey questionnaires were posted to all companies that market substitutable medicines and had an office in Finland in 2004 and in 2007-2008. The response rate in both surveys was $56 \%$. This is comparable or higher than in some survey studies posted to pharmaceutical companies $[43,44]$ or companies from different industries in Finland $[43,45]$, in which response rate has varied between 24 and 52\%. However, the study population was small and this should be taken into account when interpreting the results of this study. This meant that, the categories of generic product companies and original product companies also included companies that marketed both original and generic products. If the study companies had been categorized differently, the results might have been different in some activities and between groups. In addition, pharmaceutical companies that marketed only generic or original products were slightly underrepresented among the survey respondents. This means caution is needed when generalizing the results of this study.
It should also be noted that results of this study are based on self-reports from the key persons of pharmaceutical companies. Consequently, it is possible that different sources (e.g. the statistics of company, the opinions of key persons) have been used when answering the questions of the survey. There is also the possibility for over- or underestimation in self-reported responses [46]. The questionnaires were returned anonymously and thus, the validity and reliability of the answers could not be investigated. However, some of our findings are in accordance with other sources, which support the validity of the responses. In addition, the background characteristics of the original product and generic product companies that responded in the 2004 and 2008 surveys were very similar. Besides, the responses especially in the original product companies were similar in both surveys. On the other hand, there were also variations in the trend of answers especially in the generic product companies between surveys. This could result from the fact that different companies responded in 2004 and 2008. Another possible reason is that impact of GS changed during the four years between the surveys. However, tracing the impact of GS 
in the same companies between years was not possible. Changes in the reported impact of GS on activities of companies between years 2004 and 2008 should be interpreted with caution.

This study was limited to the experiences of pharmaceutical companies in Finland. The operating environment of pharmaceutical companies and the practices of GS vary between countries. This means caution is needed when comparing the results from other countries. For instance, there is much variation in the size and structure of the pharmaceutical markets and the number of pharmaceutical companies that operate in the market between countries $[1,34,36]$. GS by pharmacists is mandatory in Finland and in some other countries (e.g. Sweden, Germany, Denmark) as well as in some of the states in United States [1,47]. However, in other countries (e.g. France, Italy, Netherlands, Norway, Portugal, Australia, Japan) as well as in most of the states in United States GS is allowed, but is not obligated [1,47-49]. Besides, GS has significantly promoted competition between pharmaceutical products $[11,50]$ and influenced the sales and gross margins of companies in Finland [7] like in some other countries (e.g. United States, Netherlands, Sweden, Denmark, Germany) $[4-6,8,10]$. However, in some countries (e.g. Italy, Spain) the impact of GS on the sales of products and competition has been smaller [5,51]. Accordingly, the impacts of GS on activities other than competition in the companies may also vary between these countries.

\section{Conclusions}

The study suggests that GS impacted the activities of pharmaceutical companies that represent mainly original or generic pharmaceutical products in Finland. In addition, there were some differences, although not statistically significant, between the surveyed original and generic product companies regarding the self-reported impacts of GS. The number of employees and amount of prescription medicine marketing decreased in many of the original product companies after the introduction of GS. In addition, the original product companies reported problems related to the storage of pharmaceutical products shortly after the reform. In the generic product companies, the prescription representatives' visits to pharmacies increased at the beginning of GS. Furthermore, GS caused problems with the storage of pharmaceuticals one year and five years after the introduction. This study was based a small group of surveyed companies and had some limitations. Further investigations are needed in this field.

\section{Acknowledgements}

We are grateful to Pharma Industry Finland and the Ministry of Social Affairs and Health for their help to conduct the study and for their valuable comments on the questionnaire. We are also grateful to the National Agency for Medicines for helping to conduct the study. The 2004 study was supported by the Ministry of Social Affairs and Health and the 2008 study was partly supported by a research grant from the Pharmaceutical Industry Research Foundation.

\section{Author details}

${ }^{1}$ School of Pharmacy/Social Pharmacy, Faculty of Health Sciences, Kuopio Campus, University of Eastern Finland, P.O.Box 1627, Fl-70211 Kuopio, Finland. ${ }^{2}$ Pharma Industry Finland, Helsinki, Finland. ${ }^{3}$ Siilinjärvi pharmacy, Siilinjärvi, Finland.

\section{Authors' contributions}

All authors participated in designing the study and discussed the findings of the study. JT collected the data, conducted the data analysis and drafted the manuscript. MB, PK and RA revised the manuscript. All authors read and approved the final manuscript.

\section{Competing interests}

The authors declare that they have no competing interests.

Received: 7 October 2009 Accepted: 22 October 2010

Published: 22 October 2010

\section{References}

1. Vogler S, Habl C, Leopold C, Rosian-Schikuta I, de Joncheere K, Thomsen T: PPRI - Pharmaceutical Pricing and Reimbursement Information Report. Vienna 2008

2. Vogler S, Espin J, Habl C: Pharmaceutical Pricing and Reimbursement Information (PPRI) - New PPRI analysis including Spain. Pharm Policy Law 2009, 11(3):213-234.

3. Hana E, Gaba D, Backa M: PPRI - Pharmaceutical Pricing and Reimbursement Information, Pharma Profile Albania, Final version. Albania 2009.

4. Congressional Budget Office: How increased competition from generic drugs has affected prices and returns in the pharmaceutical industry. The Congress of the United States Congressional Budget Office 1998.

5. Simoens S, De Coster S: Sustaining generic medicines markets in Europe. Katholieke Universiteit Leuven Centre for Pharmaceutical Care and Pharmacoeconomics, Belgia 2006.

6. Andersson KA, Petzold MG, Allebeck P, Carlsten A: Influence of mandatory generic substitution on pharmaceutical sales patterns: a national study over five years. BMC Health Serv Res 2008, 8:50.

7. Timonen J, Karttunen P, Bengtström M, Ahonen R: The impact of generic substitution on the turnover and gross margin of pharmaceutical companies a survey 1 year and 5 years after the introduction of generic substitution in Finland. Health Policy 2009, 92(2):116-123.

8. Boersma C, Klok RM, Bos JM, Naunton M, van den berg PB, de Jon-van den berg LTW, Postma MJ: Drug costs developments after patent expiry of Enalapril, Fluoxetine and Ranitidine: A study conducted for the Netherlands. Appl Health Econ Health Policy 2005, 4(3):191-169.

9. Buzzelli C, Kangasharju A, Linnosmaa I, Valtonen $\mathrm{H}$ : Impact of generic substitution on pharmaceuticals prices and expenditures in OECD countries. J Pharm Fin EC Polic 2006, 15(1):41-63.

10. Engström A, Jacob J, Lundin D: Sharp drop in prices after the introduction of generic substitution. Pharmaceutical Benefits Board, Solna 2006.

11. Aalto-Setälä $V$ : The impact of generic substitution on price competition in Finland. Eur J Health Econ 2008, 9(2):185-191.

12. Andersson K, Berström G, Petzold MG, Carlsten A: Impact of a generic substitution reform on patients' and society expenditure for pharmaceuticals. Health Policy 2007, 81(2-3):376-384

13. Ministry of Social Affairs and Health: Lääkkeiden viitehintajärjestelmää selvittäneen työryhmän muistio [Memorandum of the Working Group on the introduction of a reference price system for medicines, abstract in English]. Reports of the Ministry of Social Affairs and Health 46 Helsinki 2007.

14. Suh D: Trends of generic substitution in community pharmacies. Pharm World Sci 1999, 21(6):260-265.

15. Rubak SLM, Andersen ME, Mainz J, Olesgaard P, Laursen K, Schaumann M, Lauritzen T: Hvordan vurderer apotekere og farmaceuter 
lægemiddelsubstitutionsordningen? [Pharmacists' evaluation of the substitution system for prescription]. Ugeskr Læger 2000 162(45):6074-6077

16. Allenet $\mathrm{B}$, Barry $\mathrm{H}$ : Opinion and behaviour of pharmacists towards the substitution of branded drugs by generic drugs: survey of 1,000 French community pharmacists. Pharm World Sci 2002, 25(5):197-202.

17. Mott DA, Cline RR: Exploring generic drug use behaviour: The role of prescribers and pharmacists in the opportunity for generic drug use and generic substitution. Med Care 2002, 40(8):662-674.

18. Andersson K, Sonesson C, Petzold M, Carlsten A, Lönnroth K: What are the obstacles to generic substitution? An assessment of the behaviour of prescribers, patients and pharmacies during the first year of generic substitution in Sweden. Pharmacoepidemiol Drug Saf 2005, 14(5):341-348.

19. Hartikainen-Herranen $K$, Ahonen R: Lääkevaihdon vaikutukset apteekkien talouteen ja toimintaan. In Lääkevaihdon ensimmäinen vuosi [The first year of generic substitution]. Edited by: Ahonen R, Martikainen J. Helsinki: The Social Insurance Institution; 2005:69-78, Social security and health reports 68.

20. Timonen J, Bengtström M, Karttunen P, Ahonen R: Haastattelututkimus lääkevaihdon vaikutuksista lääketukkukauppaan Suomessa vuosina 2004 ja 2008 (An interview study of the impact of generic substitution on wholesale pharmaceutical companies in Finland in 2004 and 2008, abstract in english). Dosis 2009, 25(3):118-131.

21. The Social Insurance Institution of Finland: Generic substitution. 2207, 03:2 [http://www.kela.fi/in/internet/english.nsf/NET/220703130721MP? openDocument]

22. National Agency for Medicines: Criteria used in compiling the list. [http:// www.nam.fi/medicines/substitutable_medicinal_products/criteria_used].

23. National Agency for Medicines: Vaihtokelpoisten lääkevalmisteiden luettelo 1.1.2009-31.3.2009. [http://www.laakelaitos.fi/ajankohtaista/3/ vaihtokelpoisten_laakevalmisteiden_luettelo_1_1_2009_31_3_2009].

24. Pharma Industry Finland: Hallituksen esitys (165/2002) eduskunnalle lääkelain ja sairasvakuutuslain muuttamisesta lääkkeiden pakkovaihdon toteuttamiseksi Suomessa. Statement for the Ministry of Social Affairs and Health 2002

25. Timonen J, Leisku K, Uusaro AK, Ahonen R: Lääkevaihto lehdistössä lääketeollisuus ja viranomaiset vastakkain [Generic substitution in the Finnish press - viewpoints of the drug industry and the authorities, abstract in english]. Dosis 2006, 22(4):316-328.

26. Vehkasaari M: Lääkevaihto ja potilasturvallisuus -seminaari Lääkäritalolla: Geneerinen substituutio heikentää hoitomyöntyvyyttä. Suom Lääkäril 2002, 57(41):4140-4142

27. Lampila J: Substituutio lääketeollisuuden näkökulmasta. Apteekkari 2003, 92(12):32-35

28. Pharma Industry Finland: Pharmaceutical industry personnel in Finland 1982-2003. In Medicines and health 2004. Edited by: Aaltonen S, Saarinen A. Helsinki: Pharmaceutical Information Centre Ltd; 2004:145.

29. Pharmaceutical Information Centre: Pharma Facts Finland 2004. Helsink 2004.

30. Pharmaceutical Information Centre: Pharma Facts Finland 2005. Helsink 2005.

31. Pharmaceutical Information Centre: Pharma Facts Finland 2006. Helsinki 2006.

32. Pharmaceutical Information Centre: Pharma Facts Finland 2007. Helsink 2007.

33. Pharma Industry Finland: Pharmaceutical industry personnel in Finland 2007 and 2008, Statistics of Pharma Industry Finland. 2009.

34. EFPIA- European Federation of Pharmaceutical Industries and Associations: The Pharmaceutical Industry in Figures. 2009 [http://www.efpia.eu/ Content/Default.asp?PagelD=559\&DoclD=4883].

35. Kangasharju A, Linnosmaa I, Pudas H, Valtonen H: Geneerinen substituutio, markkinarakenne ja hinnat Suomen lääkemarkkinoilla. In Terveystaloustiede 2007. Edited by: Klavus J. Helsinki: Stakes; 2007:33-35.

36. Commission European: Pharmaceutical Sector Inquiry, Final report. 2009 [http://ec.europa.eu/competition/sectors/pharmaceuticals/inquiry/index. $\mathrm{html}]$

37. Honkanen H: Farmaseuttien kokemuksia lääkemarkkinoinnista ja itsehoitolääkkeiden suositteluperusteista - teemahaastattelu apteekkifarmaseuteille (Pharmacists' experiences of drug marketing and OTC-medicine recommendations, abstract in english). Master's thesis University of Kuopio, Social Pharmacy, Kuopio 2006.
38. Kjoenniksen I, Lindbaek M, Granas AG: Patients' attitudes towards and experiences of generic drug substituion in Norway. Pharm World Sci 2006, 28(5):284-289.

39. Heikkila R, Mäntyselkä P, Hartikainen-Herranen K, Ahonen R: Customers' and physicians' opinions of and experiences with generic substitution during the first year in Finland. Health Policy 2007, 82(3):366-374.

40. Lilja J, Salek S, Alvarez A, Hamilton D: Marketing of drugs. Pharmaceutical Systems England: John Wiley \& Sons Ltd 2008, 219-235.

41. Andersin M: Lääkemarkkinointi läke-edustajien näkökulmasta teemahaastattelu lääke-edustajille (Medicinal marketing. Pharmaceutical representative's view point - theme interview, abstract in english). Master'e thesis University of Kuopio, Social Pharmacy, Kuopio 2007.

42. Pharma Industry Finland: Market share of original, generic and parallel imports products in Finnish pharmaceutical market 2000-2009, Statistics of Pharma Industry Finland. 2010.

43. Harzing A: Cross-national industrial mail surveys: why do response rates differ between countries? Ind Market Manag 2000, 29(3):243-254.

44. Geitona M, Kyriopoulos J, Zavras D, Hatzikou M: Generics market in Greece: the pharmaceutical industry's beliefs. Health Policy 2006, 79(1):35-48.

45. Liljeblom E, Vaihekoski M: Owners' way or the highway: short term expectations and owner impatience. Hanken's Research Report 622007 Swedish School of Economics and Business Administration Svenska handelshögskolan.

46. Smith F: Research Methods in Pharmacy Practice London: Pharmaceutical Press 2002.

47. Berg MJ, Gross RA, Haskins LS, Zingaro WM, Tomaszewski KJ: Generic substitution in the treatment of epilepsy: Patient and physician perceptions. Epilepsy and Behaviour 2008, 13(4):693-699.

48. Beecroft G: Generic drug policy in Australia: a community pharmacy perspective. Aust New Zealand Health Policy 2007, 4:7.

49. Simoens S: Developing the Japanese generic medicine market: What can we learn from Europe? Journal of Generic Medicines 2009, 6(2):129-135.

50. Galizzi M, Ghislandi s, Hokkanen J, Kangasharju A, Linnosmaa A, Miraldo M, Valtonen $\mathrm{H}$ : Reference pricing in Finnish pharmaceutical markets: Prepolicy evaluation. Reports of the Ministry of Social Affairs and Health 25 Ministry of Social Affairs and Health, Finland 2009.

51. Ghislandi S, Krulichova I, Garattini L: Pharmaceutical policy in Italy: towards a structural change? Health Policy 2005, 72:53-63.

\section{Pre-publication history}

The pre-publication history for this paper can be accessed here: http://www.biomedcentral.com/1472-6904/10/15/prepub

doi:10.1186/1472-6904-10-15

Cite this article as: Timonen et al:: The impact of generic substitution on the activities of pharmaceutical companies - a survey from the companies' perspective one year and five years after the introduction of generic substitution in finland. BMC Clinical Pharmacology 2010 10:15.

\section{Submit your next manuscript to BioMed Central and take full advantage of:}

- Convenient online submission

- Thorough peer review

- No space constraints or color figure charges

- Immediate publication on acceptance

- Inclusion in PubMed, CAS, Scopus and Google Scholar

- Research which is freely available for redistribution 